\title{
Correction: Screening for cancer in patients with
}

unprovoked venous thromboembolism: protocol for a systematic review and individual patient data meta-analysis

van Es N, Gal GL, Otten H, et al. Screening for cancer in patients with unprovoked venous thromboembolism: protocol for a systematic review and individual patient data meta-analysis. BMJ Open 2017;7:e015562. doi: 10.1136/bmjopen-2016-015562

The author name 'Luis Jara Palomares' should be spelled 'Luis Jara-Palomares' where 'Luis' is the first name and 'Jara-Palomares' is the surname.

Open Access This is an Open Access article distributed in accordance with the Creative Commons Attribution Non Commercial (CC BY-NC 4.0) license, which permits others to distribute, remix, adapt, build upon this work non-commercially, and license their derivative works on different terms, provided the original work is properly cited and the use is non-commercial. See: http://creativecommons.org/licenses/by-nc/4.0/

C Article author(s) (or their employer(s) unless otherwise stated in the text of the article) 2017. All rights reserved. No commercial use is permitted unless otherwise expressly granted.

BMJ Open 2017;7:e015562corr1. doi:10.1136/bmjopen-2016-015562corr1 